\title{
Dairy Supply Chain Risk Management in Bangladesh: Field studies of Factors and Variables
}

\author{
Tasnuba Nasir ${ }^{1}$, Mohammed Quaddus ${ }^{1}$, Mohamamd Shamsuddoha ${ }^{2 *}$
}

\begin{abstract}
Supply chain risk management (SCRM) has gained wide attention among the academia and the business community in the present competitive business world. This paper aims to investigate the main risk factors associated with the dairy industry along with focuses on possible mitigation strategy to mitigate those risks. Qualitative field study has been undertaken in this research. The results of the interviews identify the different risk issues along with the possible mitigation strategies, embedded at storage, processing and distribution level in dairy industry of Bangladesh. The practical implication will contribute significantly to the dairy sector in terms of mitigating risks.
\end{abstract}

Keywords: Dairy industry, supply chain risk, supply chain risk management

\section{Introduction}

In every dimension of our lives, we have to encounter and manage risks. The idea of risk and risk management is not a modern contrivance. In order to increase efficiency and reactivity every business organisations are forced to manage their supply chain effectively (Thun and Hoenig [1]). The concept of supply chain risk management is rapidly developing with high rate in the contemporary business world. Supply chain members have to face and manage a number of risks in their increasingly competitive environment (Giunipero and Eltantawy [2]). Therefore, risk management could be a more effective approach to deal with several risks associated with business by identifying possible losses. Supply chain risk management is a mechanism, which aims at mitigating the negative impact of disturbance and tries to manage certain risks within supply chain. It is a process of identification of risks and mitigation of them through outcome development (Mishra and Shekhar [3]). The dairy supply chain comprises of dairy farms, Storage and processing facilities, wholesale distributors, and retailers (Curtis [4]). As it involves many stakeholders, risks may arise from any component within its supply chain. The main risk associated with Bangladesh dairy may arise from economic sources (land scarcity, financial unavailability, technology disruption, improper feeding etc.), social sources (political unrest, policy barrier, contamination etc.) and environmental sources (natural disaster, diseases).

\footnotetext{
${ }^{1}$ School of Marketing, Curtin University, 78 Murray Street, Perth WA 6000, Australia. Email: tasnuba2003@yahoo.com, Mohammed.Quaddus@gsb.curtin.edu.au,

${ }^{2}$ Department of Marketing, University of Chittagong, Bangladesh. Email: msdoha@gmail.com

${ }^{*}$ Corresponding author
}

In Bangladesh, dairy is a popular live stocksubsector in rural economy and as well as a powerful avenue for additional income generation which is passed on to next generation through inheritance.

Thus dairy is an important and growing sector of Bangladesh's economy, which is increasingly proving to be a worthwhile livelihood option for a large number of households engaged in milk production and trade. But this business is comparatively risky as the main product (milk) with which the industry deals in, is quick perishable in nature, which get multiplied the risks (Mishra and Shekhar [3]). The dairy industry stakeholders are confronted with multiple risk factors including low productivity, seasonal variations, limited and poor infrastructural facilities, irregular supply of vaccine, high cost of feed and medicine, limited availability of pastures and water and absence of fixed government policy. Although in recent years, in the field of supply chain management, the domain of supply chain risk management has gained widespread attention by academicians and practitioners but it is still in infancy in dairy sector. Empirical work is needed in the field of supply chain risk management analysing the main supply chain risks and exploring instruments for an effective supply chain risk management particularly in Bangladesh dairy sector.

\section{Research Background}

Bangladesh is an agro based country with a land area of 130,000 square kilometres of which 69.4 percent is classified as agricultural land (FAOSTAT [5]). Dairy, Poultry and Fisheries are the main occupation of the rural people (Shahnaz, et al. [6]). Dairy is the most important livestock subsector in the economy of Bangladesh as it provides energy in the form of draft and traction power for various activities. Various 
activities includes fuel for cooking and other heating purposes; food in the form of milk, milk products and meat; raw materials in the form of wool, hair, skins, hides, bones, hoof and horns; manure for crops and cow dung for fuel (Halder and Barua [7]). According to DLS [8], the numbers of livestock in Bangladesh are estimated to be 22.6 million cattle, 1.06 million buffalo, 18.4 million goats, 2.38 million sheep, 164.1 million fowls, and 13.5 million ducks (cited in Bari, [9]). The milk production was 2.27 million tonnes in 2006 (Haque [10]). At present, there are fourteen structured industries which are operating dairy business in Bangladesh, among them Milkvita, BRAC and PRAN are holding top most market shares (Haque [10]). Bangladesh dairy is beset with different risks in its different sectors. Land scarcity, feed scarcity, inadequate treatment and credit facilities, poor infrastructure and logistic support are the major risks in input sector (Karim et al. [11], Bari [9], Ghosh and Maharjan [12]). Production and processing activities are affected by the poor functioning of the input sector with added risks such as adulteration, absence of technical know-how, and mismanagement of staff (Shamsuddoha and Edwards [13], Bari [9]). However distribution and marketing of Bangladesh dairy is also not free from risks. The main risks associated with distribution are adulteration, deprivation by middlemen, long chain of distribution, poor transport facilities, limited access to market (Halder and Barua [7]). Beside these risks there could be various other forms of risks which hinder the development of dairy supply chain in Bangladesh. Proper identification and frequent awareness of these risks will lead to the development of effective mitigation strategies for both private and public dairy industries to improve supply chain performance of the sector.

Supply Chain which is a network of connected and interdependent organisations, working together mutually and cooperatively, to control, manage and improve the flow of material and information from suppliers to end users (Aitken [14]). The dairy supply chain begins when dairy farms produce raw milk. The raw milk is supplied to processing centre to process the raw milk into consumable milk or other dairy products. Once processing is completed, milk is transported to wholesale distributors. From the wholesale distributors, the milk goes to the retailers where it is purchased by consumers. This is a general flow of formal dairy supply chain. In the case of informal dairy supply chain, after producing raw milk it is supplied to milk traders (Ghosh, Goala, wholesalers), retailers (sweetshop, tea stall, local hotel etc.) and local consumers . Mishra [3] has done a survey based research on dairy in where he mentioned that supply chain in any industry is entangled with many stakeholders and it is a complex bonding of several stakeholders, distortion at one of the components distorts the entire chain in varying degrees. Supply chain risks and the associated financial and operational risks are the most burning issues for all firms, which are unplanned and unanticipated events disrupt the normal flow of products (Svensson [15], Hendricks and Singhal [16]). Different organisations perceive the risks that arise across the supply chain in different ways. Some organisations accept the risks with taking appropriate measures and some organisations avoid the risks by staying at safe side of the risks. Whatever is the attitude of organisation, there must have impact of risks throughout the chain.

Thun and Hoenig [1] conducted a survey of 67 manufacturing plants in German automotive industry to identify and examine the key drivers of supply chain risks. They found that outsourcing; transportation risk, cultural risk, exchange rate risk and some other catastrophe (terrorist attack, bankruptcy, and financial losses) are some of the key drivers for disrupting supply chain. Supply chain risk management is the management of supply chain risk through coordination or collaboration among the supply chain partners so as to ensure profitability and continuity (Tang [17]). This process starts with identification of the risks and ends with the risk mitigation through the risk avoidance, risk transferring (Mishra, [3]), cooperating, controlling (Jüttner, et al. [18]). After reviewing literature related to supply chain, Rao \& Goldsby [19] identified some sources of risks which consisted of environmental factors, organisational factors and social factors. Political instability, shift in government policy, social uncertainties and natural uncertainties are the primary variables of environmental risks (Miller [20]). Thun and Hoenig [1] conducted a survey of 67 manufacturing plants in German automotive industry to identify and examine the key drivers of supply chain risks. They found that outsourcing; transportation risk, cultural risk, exchange rate risk and some other catastrophe (terrorist attack, bankruptcy, and financial losses) are some of the key drivers for disrupting supply chain.

The researchers used two approaches namely, preventive approach and reactive approach and the results showed that the group using reactive supply chain risk management had higher average value in terms of disruptions resilience or the reduction of the bull whip effect, whereas the group pursuing preventive supply chain risk management had better values concerning flexibility or safety stock. Mishra and Shekar [3], in their research identified some dairy risks by conducting in-depth personal interviews with different corporate authorities. In their 
findings the major risks were; logistic risk, hazard risk, high cost of food, low risks, product shortage, delivery risk and lack of skilled staff etc. Farmers in rural areas rely on middlemen to sell their product, where the middlemen deprive them by taking maximum share (Ghani and Rahman [21]). After production there is a need to preserve the raw milk in the chilling centre. Disruption in supply of power at chilling centre and the processing plant, shortage in treated water and flawed machineries may disrupt the operational activities of industry which may affect the quality of product, profitability (Food [22]). Climatic condition (hot weather, too much humidity) may create risks for dairy if the cold chain cannot be maintained properly (Faye and Loiseau [23]). Drought, flood, diseases are the biggest risk factors, which cause unpredictability in milk production, leading to financial losses to the dairy industry (Choudhary et al. [24]).

As a mitigation strategy, Jüttner et al. [18] have suggested four generic strategies which are avoidance, control, cooperation and flexibility. For the perishability nature of milk (main product of dairy), dairy industries need to adopt some mitigation strategies either to prevent the risks or reduce the risks. In order to mitigate the dairy risks it is necessary to overcome economic as well as technical constraints (Shamsuddoha and Edwards [13]). Economic constraints could be overcome by providing loan facilities whereas technical constraints could be overcome by improving breeds, feed and production methods. In Asian Productivity Organization (APO) conference, Khanna [25] has suggested Total Quality Management (TQM) approach as risk mitigation policy, where improvement of the quality has to follow the entire chain from the producer's doorstep to arrival of products to the consumer. This approach includes good hygiene practices, good housekeeping, and good manufacturing practices. Training programme for the employees could be another strategy for mitigating risks. To increase lifetime productivity of dairy animal, farmers need to be properly trained in management practices (Khanna [25]).

Although it is seen that, different literatures illustrates different risk sources and risk management approaches in supply chain but still literature on the dairy sector supply chain risk management study is found to be limited particularly, in the context of Bangladesh. This research will develop a new framework that integrates the sustainable components to categorise risks in supply chain and provide possible risk mitigation strategies, which will contribute significantly on the theoretical and practical aspects of dairy supply chain risk management.

\section{Methods}

As a research paradigm the qualitative field study has been undertaken in this research (Zikmund et al. [26]). Since this study is engaged in exploring risk factors along with mitigation strategies in dairy sector, so the qualitative field study is the appropriate method because qualitative field study is well apposite for new and inadequate research areas (Eisenhardt [27]). Data in a field study can be collected via different methods. Here we have chosen the interview method as in obtaining qualitative data interviewing has been proven to be very effective and common method (Whiteley et al. [28]). In performing the exploratory study, in subsequent stages, the review of the literatures have been done to identify, collated and modify (where needed) the important factors while factors are contextualised, confirmed and modified during the field study. A semi-structured interview questions has been adopted from the literature. See the Appendix for the excerpt of the questionnaire.

\section{Research Sampling}

The sample of this study based on availability and easy accessibility of subjects who were close at hand (Zikmund [29]). The main criteria for selecting the subjects were the position and the experience of them in their organisation. So purposive sampling has been employed in this research (Corbin and Strauss [30]), where 10 Interviewees, including employers and employees from two semi structured formal dairy industries with long experience in dairy sector, were invited via telephone to participate in the field study. In two participating companies, that is, company I and company II, five interviews were conducted for each company, respectively. All the participants took part in this research voluntarily. Table 1 summarizes the demographic information of each organisation.

\section{Data Collection}

A semi-structured interview technique was designed to collect data. The participants were given a clear outline of the research purpose before the beginning of each interview. The interviews were recorded with the permission of the participants and notes were taken immediately throughout the interview. The average interview time was around 1 hour. Whenever needed, the interviewer inserted the questions into conversation and prompted. The recorded interview was transcribed immediately and reviewed rigorously by the researcher in order to reflect the sense of the interview fresh from memory. 
Table 1. Demographic information of interviewee

\begin{tabular}{|c|c|c|c|c|c|c|}
\hline \multirow[b]{2}{*}{ Farm } & \multirow[b]{2}{*}{ Respondents } & \multirow[b]{2}{*}{ Position } & \multirow[b]{2}{*}{ No. of years at work } & \multicolumn{3}{|c|}{ About the farms } \\
\hline & & & & $\begin{array}{c}\text { Size } \\
\text { (Number of employees) }\end{array}$ & Age of farm & No. of livestock \\
\hline \multirow[t]{5}{*}{ I } & $\mathrm{A}$ & Managing director & 25 & \multirow[t]{5}{*}{ (2) } & \multirow{5}{*}{24} & \multirow{5}{*}{460} \\
\hline & $\mathrm{B}$ & Production manager & 12 & & & \\
\hline & $\mathrm{C}$ & Supervisor & 10 & & & \\
\hline & $\mathrm{D}$ & Farm Manager & 12 & & & \\
\hline & $\mathrm{E}$ & Supervisor & 9 & & & \\
\hline \multirow[t]{5}{*}{ II } & $\mathrm{F}$ & Supervisor & 13 & \multirow{5}{*}{48} & \multirow{5}{*}{27} & \multirow{5}{*}{375} \\
\hline & $\mathrm{G}$ & Supervisor & 8 & & & \\
\hline & $\mathrm{H}$ & Farm Manager & 15 & & & \\
\hline & I & Supervisor & 11 & & & \\
\hline & $\mathrm{J}$ & Supervisor & 10 & & & \\
\hline
\end{tabular}

\section{Data Analysis}

In qualitative research, data analysis is one of the challenging jobs. There are numerous tools and techniques are available in different literatures (Miles and Huberman [31]). Researcher must select the tool(s) on the basis of the objective of the research (Quaddus and $\mathrm{Xu}$ [32]). Since this research is exploratory in nature, for analysing collected data from the interview, content analysis technique has been chosen (Berg [33]). From ten interviews, there were more than hundred pages of interview scrips to analyse. From the content analysis, different factors and variables were explored. It is mentionable here that all content analysis were done manually and both inductive and deductive approaches was used to scan and categorise the factors and variables from the raw data to fulfil the objective of this study (Berg [33]).

In inductive phase, factors and their corresponding variables were explored by reviewing the transcript line by line. After that, labels for these factors and variables were produced. A number of free nodes were developed by naming each segment of data with a label. Later, tree nodes were developed from a set of relevant free nodes with a similar concept. For example, when the respondents were asked about dairy supply chain risk issues, 26 variables (free node) were explored. After combining the variables with similarities, 19 variables came up as distinct variables. Afterwards, these variables were grouped into seven nodes, named as "financial risk", "technological risk", "human resource risk", "government policy and support", "political risk", "mismanagement of staff" and "natural risk". After finishing inductive phase, the factors and variables which were found in the field study, were matched with those from the literature, in deductive phase, without deducting any factors and variables obtained from the interview.

\section{Results and Discussions}

This section consists of the result and discussion of the qualitative data analysis. All variables, derived from the interviews, were summarised in a comprehensive table, which is presented at the end of this section.

\section{Demographic Information}

Table 1 represents the demographic information of the farms involved in the field study. There are two medium scale farms, which are recently growing and confronting different risks to mitigate. But both of the farms have history for many years. The number of the employees range from 40 to 60 . The interviewees' positions varied from managing director to general staff and their tenures ranged from 8 to 25 years. The last column of the table shows the number of present livestock holding by both farms, from which farm size could be realised.

\section{Factors and Variables}

A number of factors and variables regarding risk issues and probable mitigation strategies have been identified from this study through extensive content analysis procedures. Later these factors and variables have been labelled, where possible, in line with the literatures (Finch [34], Jüttner, et al. [18], Mishra and Shekhar [3], Rao and Goldsby [19], Choudhary et al. [24], Akcaoz, et al.[35], Carter and Rogers [36], Raha and Talukder [37], Blos et al.[38], Manuj and Mentzer [39], Chowdhury [40] . From the content analysis, it is found that dairy supply chain in Bangladesh is associated with different types of risks in its different sector. These risk issues hinder the growth and development of dairy industry in Bangladesh. As the interviewee $\mathrm{F}$ from the farm II said 'The dairy farming system, in our country could be expanded if the risks could be mitigated properly'. 
To mitigate the risks that arise from economic, social and environmental aspects, company and government have to take some mitigation strategies. So all the respondents in the field study stressed to implement various mitigation strategies in different sectors (storage, processing and distribution) to mitigate the risk. For example, respondent $\mathrm{C}$ from Farm I stated that, 'The risk of storage level could be mitigated by improving technologies and removing political uncertainties'. In line, another participant F, from Farm I, mentioned that, 'Sometimes we fail to distribute our product timely due to political uncertainties....in that case we have to store product for long time which emergence the need for more capacity in cold storage'.

\section{Risk Factors}

The respondents of the field study focused on the existence of several risk issues at storage, processing and distribution level in Bangladesh dairy. It is noted here that 19 variables regarding risk issues were found in common at every levels. At storage level, 6 variables, at processing level 13 variables and at distribution level, 7 variables were found specifically. Some of the risks were occurred due to hazard, while number of risks is associated with low financial capabilities and technological shortage. A few of them are socially responsible (political, unethical behaviour of employees, lack of government support etc.), whereas some of the risks are action of God which are natural ( flood, storm etc.). Again, some risks are affecting the processing activeties and can be termed as input risk, whereas a number of risks arise due to poor infrastructural facilities at distribution level. All risk factors and variables are shown in Table 2, 3, 4 and 5. The most usual and domineering risk factors and mitigation strategies are explained in the below sections.

\section{Financial Risk}

From the interview, a number of financial risks have been found which have direct influence on the activities of all levels (storage, processing and distribution). These risks arise from different financial occurrences that often hinder the growth and development of dairy, subsequently affect the actions of supply chain. Respondents talked about different financial risks such as inadequate loan facilities, complex loan procedures, high interest rate, inadequate finance and lack of insurance coverage. Regarding loan facility, respondent F mentioned that 'Most of the financial institution in our country are not interested to invest in dairy sector i.e. they are not interested to give loan to the dairy industry'.
He also added that 'the existing loan procedure is too complex'. Another participant A mentioned that, 'Inadequate loan and inadequate finance are affecting the growth of their organisation'. He also lined that, 'the rate of interest is just too high'.

\section{Technological Risk}

Some of the risks arise from technological shortage. Respondents have mentioned a number of technological shortage for which their production and operational activities are hampered and slowed down. Technological shortage includes inadequate chilling system, shortage of cold room, and absence of mechanised milking, feed mixture, Improved processing facilities and so on. For example, respondent G said about technological advancement that, 'Still we are used to milking manually which is time consuming ,required more staff involvement and also increase the risk of mismanagement and pollution'.

\section{Human Resource Risk}

Human resource risks have been decomposed into labour dispute, illiteracy and inefficiency of worker, shortage of skilled staff and frequent staff switching. Farming business need efficient and experienced human resource. In this regard, respondent $\mathrm{F}$ from farm II struggling to keep the staff for long time. He uttered that, 'After trained the staff and making them skilled, they switch way'. Shortage of skilled and efficient workers linger the processing activities.

\section{Absence of Fixed Government Policy}

Lack of fixed policy of government regarding dairy industry and the poor law and order situations have direct impact on storing, processing and distributing functions of dairy production. Majority of the respondents reported that there is a lack of fixed government policy regarding feed management, breed management, loan disbursement and central distribution of milk. Moreover, legal and regulatory framework of the country is also characterised by poor and non-transparent administrative and judicial system, bureaucratic complexities, political interference and muscleman ship, terrorism etc. These are significantly affecting the smooth running of dairy industry in the country. For example respondent $\mathrm{F}$ revealed that, 'Sometimes we have to handle some unfair situation, which could be solved by the interference of political leader ... but it needs financial contribution to them'. Another respondent $\mathrm{H}$ stated that, 'For getting easy loan we have to maintain a good relationship with the officers by giving them bribe and other facilities'. 
Table 2. Common Risk Factors and Variables in All levels (Storage, Processing and Distribution)

\begin{tabular}{|c|c|c|c|c|c|c|c|c|c|c|c|c|}
\hline \multirow{2}{*}{$\begin{array}{l}\text { Sustainability } \\
\text { aspects }\end{array}$} & \multirow{2}{*}{ Risk factors } & \multirow{2}{*}{ Risk variables } & \multicolumn{5}{|c|}{$\mathrm{I}$} & \multicolumn{5}{|c|}{ II } \\
\hline & & & $\mathrm{A}$ & $\mathrm{B}$ & $\mathrm{C}$ & $\mathrm{D}$ & $\mathrm{E}$ & $\mathrm{F}$ & $\mathrm{G}$ & $\mathrm{H}$ & $\mathrm{I}$ & $\mathrm{J}$ \\
\hline \multirow[t]{6}{*}{ Economical } & Financial risk & Inadequate loan facilities & $\mathrm{y}$ & & & $\mathrm{y}$ & & & & & & $\mathrm{y}$ \\
\hline & & Complex loan procedures & & & & & & $\mathrm{y}$ & & & & \\
\hline & & High rate of interest & $\mathrm{y}$ & & & & & & & & & \\
\hline & & Inadequate finance & & & $\mathrm{y}$ & & $\mathrm{y}$ & $\mathrm{y}$ & $\mathrm{y}$ & $\mathrm{y}$ & $\mathrm{y}$ & $\mathrm{y}$ \\
\hline & & $\begin{array}{l}\text { Absence of insurance or compensation } \\
\text { coverage for dairy industry }\end{array}$ & $\mathrm{y}$ & & & & & $\mathrm{y}$ & & & & \\
\hline & $\begin{array}{l}\text { Technological } \\
\text { shortage }\end{array}$ & $\begin{array}{l}\text { Shortage of improved technology } \\
\text { (Milking machine, feed mixture, grass } \\
\text { cutting, improved processing, cooling } \\
\text { facilities) }\end{array}$ & & & & $\mathrm{y}$ & & $\mathrm{y}$ & $\mathrm{y}$ & & & \\
\hline \multirow[t]{11}{*}{ Social } & Human resource & Labour disputes & $\mathrm{y}$ & & $\mathrm{y}$ & $\mathrm{y}$ & & & $\mathrm{y}$ & $\mathrm{y}$ & & $\mathrm{y}$ \\
\hline & risk & Illiteracy and inefficiency of worker & $\mathrm{y}$ & & & & $\mathrm{y}$ & & & & $\mathrm{y}$ & \\
\hline & & Shortage of skilled staff & $\mathrm{y}$ & & & & $\mathrm{y}$ & $\mathrm{y}$ & & & & \\
\hline & & Switching of staff frequently & $\mathrm{y}$ & & & $\mathrm{y}$ & & $\mathrm{y}$ & & & & $\mathrm{y}$ \\
\hline & $\begin{array}{l}\text { Government policy } \\
\text { and support }\end{array}$ & $\begin{array}{l}\text { Lack of fixed government policy in } \\
\text { dairy sector }\end{array}$ & $\mathrm{y}$ & $\mathrm{y}$ & $\mathrm{y}$ & $\mathrm{y}$ & $\mathrm{y}$ & & $\mathrm{y}$ & $\mathrm{y}$ & & \\
\hline & & $\begin{array}{l}\text { Poor law and order situation } \\
\text { (terrorism, musclemen ship) }\end{array}$ & & & & & & $\mathrm{y}$ & & $\mathrm{y}$ & & \\
\hline & Political risk & $\begin{array}{l}\text { Hartal and strike cause delay in } \\
\text { working process }\end{array}$ & $\mathrm{y}$ & $\mathrm{y}$ & $\mathrm{y}$ & $\mathrm{y}$ & $\mathrm{y}$ & & $\mathrm{y}$ & $\mathrm{y}$ & $\mathrm{y}$ & $\mathrm{Y}$ \\
\hline & & Political Unrest and interference & $\mathrm{y}$ & $\mathrm{y}$ & $\mathrm{y}$ & & $\mathrm{y}$ & $\mathrm{y}$ & $\mathrm{y}$ & $\mathrm{y}$ & $\mathrm{y}$ & $\mathrm{Y}$ \\
\hline & $\begin{array}{l}\text { Mismanagement } \\
\text { and unethical }\end{array}$ & $\begin{array}{l}\text { Corruption (Adulteration by mixing } \\
\text { water) }\end{array}$ & $\mathrm{y}$ & $\mathrm{y}$ & & $\mathrm{y}$ & $\mathrm{y}$ & $\mathrm{y}$ & & & & \\
\hline & behaviour of & Damage of farm's assets & & & $\mathrm{y}$ & $\mathrm{y}$ & $\mathrm{y}$ & $\mathrm{y}$ & $\mathrm{y}$ & $\mathrm{y}$ & & \\
\hline & employees & Theft & $\mathrm{y}$ & $\mathrm{y}$ & $\mathrm{y}$ & & $\mathrm{y}$ & $\mathrm{y}$ & $\mathrm{y}$ & $\mathrm{y}$ & & \\
\hline \multirow[t]{2}{*}{$\begin{array}{l}\text { Environmen- } \\
\text { tal }\end{array}$} & Natural risk & $\begin{array}{l}\text { Natural uncertainties (storm, } \\
\text { excessive rain, flood) }\end{array}$ & & & & $\mathrm{y}$ & $\mathrm{y}$ & & $\mathrm{y}$ & & $\mathrm{y}$ & $\mathrm{Y}$ \\
\hline & & Quick perishability of Milk & & $\mathrm{y}$ & & $\mathrm{y}$ & & & & & & \\
\hline
\end{tabular}

Table 3. Qualitative data with risk factors and variables (storage level)

\begin{tabular}{|c|c|c|c|c|c|c|c|c|c|c|c|}
\hline \multirow{3}{*}{$\begin{array}{c}\text { Sustainability } \\
\text { aspects }\end{array}$} & \multirow{3}{*}{ Risk factors } & \multirow{3}{*}{$\begin{array}{c}\text { Risk } \\
\text { Variables }\end{array}$} & \multicolumn{9}{|c|}{ Respondents } \\
\hline & & & \multicolumn{5}{|c|}{ Farm I } & \multicolumn{4}{|c|}{ Farm II } \\
\hline & & & $\mathrm{A}$ & $\mathrm{B}$ & $\mathrm{C}$ & $\mathrm{D}$ & $\mathrm{E}$ & $\mathrm{F}$ & G & $\mathrm{H} \quad \mathrm{I}$ & $\mathrm{I} \mathrm{J}$ \\
\hline \multirow[t]{3}{*}{ Economical } & Hazard risk & Machine damage/breakdown at cold storage & $\mathrm{y}$ & & & & & & $\mathrm{y}$ & $\mathrm{y}$ & $\mathrm{Y}$ \\
\hline & Technological & Inadequate chilling facilities & & $\mathrm{y}$ & & $\mathrm{y}$ & & & & & \\
\hline & shortage & Inadequate cold storage facilities & & $\mathrm{y}$ & & & $\mathrm{y}$ & $\mathrm{y}$ & & & \\
\hline Social & $\begin{array}{l}\text { Mismanagement } \\
\text { and unethical } \\
\text { behaviour of } \\
\text { employees }\end{array}$ & Spoilage of milk through improper handling & & & $\mathrm{y}$ & & $\mathrm{y}$ & $\mathrm{y}$ & $\mathrm{y}$ & $\mathrm{y}$ & \\
\hline Environmental & $\begin{array}{l}\text { Environmental } \\
\text { risk }\end{array}$ & $\begin{array}{l}\text { Bacterial contamination for improper } \\
\text { temperature } \\
\text { Pollution and } \\
\text { Unhygienic environment }\end{array}$ & & & & & & $\mathrm{y}$ & & $\mathrm{y}$ & Y \\
\hline
\end{tabular}

\section{Political Risk}

The political environment of Bangladesh, which is affected by hartal (stopping of normal life by politicians or due to various protests), strike and much more political instability, hamper the continuity of production cycle. All respondents have uttered these risks that have direct influence on processing and distribution activities. A series of prolonged hartal and strike cause delay in whole process. 'Sometimes for political uncertainties we have to preserve large quantity of milk.... when we need to arrange more room for our chiller to store undistributed product', said respondent D. Another respondent $\mathrm{J}$ mention that, 'Last year 3 of our milk van were attacked and completely damaged by the picketers at the time of distribution which resulted financial loss for us.' 
Table 4. Qualitative data with risk factors and variables (processing level)

\begin{tabular}{|c|c|c|c|c|c|c|c|c|c|c|c|c|}
\hline \multirow{3}{*}{$\begin{array}{l}\text { Sustainability } \\
\text { aspects }\end{array}$} & \multirow{3}{*}{ Risk factors } & \multirow{3}{*}{ Risk Variables } & \multicolumn{10}{|c|}{ Respondents } \\
\hline & & & \multicolumn{5}{|c|}{ Farm I } & \multicolumn{5}{|c|}{ Farm II } \\
\hline & & & $\mathrm{A}$ & $\mathrm{B}$ & $\mathrm{C}$ & $\mathrm{D}$ & $\mathrm{E}$ & $\mathrm{F}$ & $\mathrm{G}$ & $\mathrm{H}$ & $\mathrm{I}$ & $\mathrm{J}$ \\
\hline \multirow[t]{9}{*}{ Economical } & Hazard risk & Cattle diseases & $\mathrm{y}$ & $\mathrm{y}$ & & & $\mathrm{y}$ & & & $\mathrm{y}$ & $\mathrm{y}$ & $\mathrm{y}$ \\
\hline & & Machine breakdown at processing unit & & & & $\mathrm{y}$ & & & $\mathrm{y}$ & & & \\
\hline & & Fire at farm shed & & & & $\mathrm{y}$ & & & $\mathrm{y}$ & $\mathrm{y}$ & & \\
\hline & & Accident (Staff injury) & & & & & & & $\mathrm{y}$ & $\mathrm{y}$ & & \\
\hline & Input risk & Inadequate supply of quality feed & $\mathrm{y}$ & & & & & & & $\mathrm{y}$ & & $\mathrm{y}$ \\
\hline & & High cost of feed and medicine & $\mathrm{y}$ & $\mathrm{y}$ & $\mathrm{y}$ & $\mathrm{y}$ & & $\mathrm{y}$ & $\mathrm{y}$ & $\mathrm{y}$ & $\mathrm{y}$ & $\mathrm{y}$ \\
\hline & & Scarcity of feed & $\mathrm{y}$ & & & & $\mathrm{y}$ & $\mathrm{y}$ & $\mathrm{y}$ & $\mathrm{y}$ & & \\
\hline & & $\begin{array}{l}\text { Lack of upgrade vaccination and } \\
\text { veterinary services }\end{array}$ & $\mathrm{y}$ & & & & & & & & & $\mathrm{y}$ \\
\hline & $\begin{array}{l}\text { Poor infrastructu } \\
\text { ral facilities }\end{array}$ & - Shortage of land for expanding farm & $\mathrm{y}$ & $\mathrm{y}$ & $\mathrm{y}$ & $\mathrm{y}$ & $\mathrm{y}$ & & $\mathrm{y}$ & $\mathrm{y}$ & $\mathrm{y}$ & \\
\hline \multirow[t]{2}{*}{ Social } & $\begin{array}{l}\text { Absence of } \\
\text { government } \\
\text { policy and } \\
\text { support }\end{array}$ & $\begin{array}{l}\text { Irregular supply of vaccine from } \\
\text { government }\end{array}$ & & $\mathrm{y}$ & & & $\mathrm{y}$ & & & & & \\
\hline & Strategic risk & $\begin{array}{l}\text { Competition among the farms } \\
\text { Bureaucratic complexity on maintaining } \\
\text { various formalities }\end{array}$ & $\mathrm{y}$ & & & & & & & $\mathrm{y}$ & $\mathrm{y}$ & $\mathrm{y}$ \\
\hline $\begin{array}{l}\text { Environmen- } \\
\text { tal }\end{array}$ & Natural risk & $\begin{array}{l}\text { Drought leads to a decline in milk } \\
\text { production }\end{array}$ & & & & & $\mathrm{y}$ & & $\mathrm{y}$ & & $\mathrm{y}$ & \\
\hline
\end{tabular}

Table 5. Qualitative data with risk factors and variables (distribution level)

\begin{tabular}{|c|c|c|c|c|c|c|c|c|c|c|c|c|}
\hline \multirow{3}{*}{$\begin{array}{l}\text { Sustainability } \\
\text { Aspects }\end{array}$} & \multirow{3}{*}{ Risk Factors } & \multirow{3}{*}{ Risk variables } & \multicolumn{10}{|c|}{ Respondents } \\
\hline & & & \multicolumn{5}{|c|}{ Farm I } & \multicolumn{5}{|c|}{ Farm II } \\
\hline & & & $\mathrm{A}$ & $\mathrm{B}$ & $\mathrm{C}$ & $\mathrm{D}$ & $\mathrm{E}$ & $\mathrm{F}$ & $\mathrm{G}$ & $\mathrm{H}$ & $\mathrm{I}$ & $\mathrm{J}$ \\
\hline \multirow[t]{6}{*}{ Economical } & Hazard risk & Accidents of transport vehicle & $\mathrm{y}$ & & & & & $\mathrm{y}$ & $\mathrm{y}$ & $\mathrm{y}$ & $\mathrm{y}$ & \\
\hline & Distribution risk & $\begin{array}{l}\text { Existence of middlemen/ too many } \\
\text { middlemen }\end{array}$ & $\mathrm{y}$ & & $\mathrm{y}$ & & & $\mathrm{y}$ & & & & $\mathrm{y}$ \\
\hline & & $\begin{array}{l}\text { Too long chain cause delay in product } \\
\text { movement }\end{array}$ & $\mathrm{y}$ & $\mathrm{y}$ & & & $\mathrm{y}$ & $\mathrm{y}$ & $\mathrm{y}$ & $\mathrm{y}$ & & $\mathrm{y}$ \\
\hline & $\begin{array}{l}\text { Poor infrastructur } \\
\text { facilities }\end{array}$ & $\begin{array}{l}\text { Poor conditioned road for moving } \\
\text { product ( delay and spoilage) }\end{array}$ & $\mathrm{y}$ & $\mathrm{y}$ & & $\mathrm{y}$ & $\mathrm{y}$ & $\mathrm{y}$ & $\mathrm{y}$ & $\mathrm{y}$ & $\mathrm{y}$ & $\mathrm{y}$ \\
\hline & & $\begin{array}{l}\text { Inadequate transport facilities to move } \\
\text { products frequently }\end{array}$ & $\mathrm{y}$ & & $\mathrm{y}$ & & & & $\mathrm{y}$ & & $\mathrm{y}$ & $\mathrm{y}$ \\
\hline & & $\begin{array}{l}\text { Lack of milk tanker with chilling } \\
\text { facilities }\end{array}$ & & $\mathrm{y}$ & & & $\mathrm{y}$ & $\mathrm{y}$ & & & & \\
\hline \multirow[t]{2}{*}{ Social } & $\begin{array}{l}\text { Mismanagement } \\
\text { and unethical }\end{array}$ & $\begin{array}{l}\text { Unethical behaviour of middle men } \\
\text { (adulteration, added price, deprivation) }\end{array}$ & & & & & & & & & & \\
\hline & $\begin{array}{l}\text { behaviour of } \\
\text { employees/ } \\
\text { middlemen }\end{array}$ & & & $\mathrm{y}$ & & $\mathrm{y}$ & & $\mathrm{y}$ & & $\mathrm{y}$ & & \\
\hline
\end{tabular}

Mismanagement and Unethical Behaviour of Employees

Mismanagement and unethical behaviour of employees are also mentioned by most of the participants in this study, where corruption (mixing water with milk), damage of farm assets, spoilage of milk through improper handling and theft were consisted. Due to the mismanagement of staff, production costs get increased. In this regard respondent A stated that 'As the income level of the people in our country is limited, so some unethical activities like theft, corruption and misuse are present in employees behaviour.....we have to aware about that, which is regular in our industry'.

\section{Natural Risk}

According to the respondent's opinion, dairy supply chain in Bangladesh is also affected by natural risks. Natural risks include natural uncertainties (flood, storm, drought, too much humidity, and heavy rainfall), Pollution and unhygienic environment, and quick perishability nature of milk. These risks bring devastating loss for all members within the supply chain network. For example, respondent A stated 
that, 'our climate is very unpredictable...sometimes moisture is high ... sometimes moisture is low.... sometimes there is too much rainfall which create problem in maintaining temperature.'

\section{Hazard Risk}

Different types of hazard risks have identified from the opinion of respondents. It is noted here that, the nature of hazard risk is different for specific level. These hazard risks include machine damage at cold storage (storage), cattle diseases, fire at farm shed, staff injury (processing) and accident of transport vehicle (distribution). Every respondent stated unanimously that cattle disease is the most frequent which has high impact in industry.

\section{Input Risk}

At processing level, there were some input risks mentioned by the participants of this study. Input risk occurs due to the disruptions to the supply of input. Inadequate supply of quality feed, scarcity of feed, lack of upgrade vaccination and veterinary services are the most cited input risk. Due to the input risk, production is hampered and production quantity is also fluctuated. All respondents except E complained about the high cost of feed and medicine that they need regularly. They also criticised about the supply of vaccine from the government which is irregular and unsatisfactory.

\section{Poor Infrastructural Facilities}

This study finds that poor infrastructural facilities not only hinder the growth and development of industry but also hamper the smooth distribution of product. For the shortage of land, farm cannot be expanded. Regarding shortage of land, respondent A mentioned that, 'We have a plan for expansion and diversification.....but cannot convert those in action as we don't have enough land resources'. Every respondent mentioned unanimously that, the poor conditioned roads and highways make delay and spoilage in moving the product.

\section{Unethical Behaviour of Middlemen}

Middlemen are present at every stage of the supply chain specifically they are very active at distribution level. Respondents considered the middleman as the "profit sucker" and wished to get rid of their unethical activities like added price, adulteration and deprivation.

\section{Risk Mitigation Strategies}

Numerous risk mitigation strategies have been explored from our analysis, which were suggested by the respondents in order to mitigate the risks associated with dairy supply chain. When probed deeper about supply chain risk mitigation strategies, different respondents put forwarded different strategies. Some of them mentioned about technological development, few of them demanded the facilities of insurance coverage, a number of respondents stressed on Training management as well as human resource management, and others focused on government support, financial management, backup capacity, off-farm income and investment, business policy and practice. Regarding mitigation strategy, respondent F stated that, 'Since we deal with living things, so risk could be occurred at any time.....we have to always ready to face and mitigate the risk'. Table 6, is presented here where all the derived variables for common (storage, processing and distribution) level are shown.

\section{Technological Development}

The most supported mitigation strategy in dairy supply chain risk management is technological development. It includes adoption of improved technology like mechanised milking, mechanised feed mixing, improved processing facilities and cold storage, adoption of RFID and so on. Most of the respondents agreed that technological development would be a means of enhancing productivity and profitability, reducing mismanagement, cost saving by less labour engagement and improving the time management.

\section{Insurance Management}

Insurance coverage against production loss can help the supply chain members to overcome different types of risks occurred from accidents, diseases, natural uncertainties and hazard risks. Regarding insurance coverage respondent A stated with frustration that, In our country, there is no insurance coverage for the dairy industry...in case of any disaster we face complexities to survive'.

\section{Human Resource Management}

In farming, as a mitigation strategy, human resource management consist of hiring skilled staff, managing them by providing motivational and incentive facilities, arrangement of training for them and building monitoring team. It is evident from the study that, skilled and efficient staffs are needed for reducing risks regarding mismanagement, temperature maintenance, and different hazard risks (machine damage, staff injury etc.). Most of the respondents stressed on training management by stating that, 'Arranging training facilities for the staffs are indispensable for making them efficient and skilled'. It also acts as motivating factor. 
Table 6. Qualitative data with common (storage, processing and distribution) mitigation Strategies

\begin{tabular}{|c|c|c|c|c|c|c|c|c|c|c|c|}
\hline \multirow{2}{*}{$\begin{array}{l}\text { Mitigation strategy } \\
\text { (Factor) }\end{array}$} & \multirow{2}{*}{$\begin{array}{c}\text { Mitigation strategy } \\
\text { (Variable) }\end{array}$} & \multicolumn{5}{|c|}{$\mathrm{I}$} & \multicolumn{5}{|c|}{ II } \\
\hline & & $\mathrm{A}$ & $\mathrm{B}$ & $\mathrm{C}$ & $\mathrm{D}$ & $\mathrm{E}$ & $\mathrm{F}$ & $\mathrm{G}$ & $\mathrm{H}$ & $\mathrm{I}$ & $\mathrm{J}$ \\
\hline Technology development & $\begin{array}{l}\text { Adoption of improved technology (Milking } \\
\text { machine, feed mixture, grass cutting, } \\
\text { improved processing facilities) }\end{array}$ & $\mathrm{y}$ & $\mathrm{y}$ & $\mathrm{y}$ & $\mathrm{y}$ & & $\mathrm{y}$ & $\mathrm{y}$ & $\mathrm{y}$ & & $\mathrm{y}$ \\
\hline Insurance Management & Buying insurance against production loss & $\mathrm{y}$ & & & & & $\mathrm{y}$ & $\mathrm{y}$ & $\mathrm{y}$ & $\mathrm{y}$ & $\mathrm{y}$ \\
\hline Human resource management & $\begin{array}{l}\text { Hiring skilled staff } \\
\text { Motivational and incentives facilities for } \\
\text { staff }\end{array}$ & & & $\begin{array}{l}\mathrm{y} \\
\mathrm{y}\end{array}$ & & $\mathrm{y}$ & & & & & \\
\hline Government support & $\begin{array}{l}\text { Initiative to remove political uncertainty } \\
\text { Implementation of a fixed policy for dairy } \\
\text { sector }\end{array}$ & & & & & & $\mathrm{y}$ & & & $\mathrm{y}$ & \\
\hline Financial Management & $\begin{array}{l}\text { Assurance of adequate institutional credit } \\
\text { support with low rate of interest } \\
\text { Introducing off-farm activities }\end{array}$ & & & & & & $\mathrm{y}$ & & $\mathrm{y}$ & & \\
\hline $\begin{array}{l}\text { Off-farm income and invest- } \\
\text { ment }\end{array}$ & $\begin{array}{l}\text { Focus on value addition and product } \\
\text { diversification } \\
\text { Promote sound business practices by }\end{array}$ & & & & & & & & & & $\mathrm{y}$ \\
\hline Business policy and practice & $\begin{array}{l}\text { cooperation, better coordination and } \\
\text { information sharing } \\
\text { Reduction of risks through merger, } \\
\text { acquisition and integration. }\end{array}$ & & & & & & & & & & \\
\hline
\end{tabular}

\section{Government Support}

All participants emphasized the need for government support regarding implantation of a fixed policy for dairy sector, removal political uncertainties, Strengthen the regular supply of vaccine , reducing cost of feed, leasing abandoned land for the dairy farmers and supporting to develop technology and infrastructure. The respondent $\mathrm{E}$ frustrated about the supply of regular vaccine from the government by stating that 'Sometimes we do not get supply of vaccine from the government at right time....then timely vaccination of the cattle could not be possible....if government will be more careful about that....then we could manage good health of farm animals which will ensure us getting a calf in each year'.

\section{Feed Management}

Feed management is another mitigation strategy for dairy supply chain risk management, which consist of focusing on certified feed supplier in order to get quality feed and regular supply of feed, confirmed by most of the respondents in this study. For example respondent $\mathrm{E}$ stated that, 'If we can manage adequate land, then we could produce more Napier grass for cattle which reduce the consumption of less concentrate feeds...as a result feed cost will be saved and production will be increased for giving more grass'.

\section{Diseases Management}

It is evident from the study that, as a mitigation strategy, a number of respondents focused on the diseases management by arranging regular, upgraded and improved vaccination for the cattle. Diseases in livestock business are very devastating. Sometimes it is such cataclysmic that the business become close down. So respondents stressed on maintaining regular vaccination for the farms live stocks.

\section{Transport Management}

Arranging adequate number of transport and refrigerated transport facilities are included in transport management, which finds as a prerequisite for effective distribution, from this study. For the quick perishability nature of milk, quick distribution is needed. Transportation and distribution need to be done in insulted vehicles to avoid excessive temperature increases. For quick and timely distribution, managing adequate transportation is must. Regarding refrigerated transport facilities, respondent F stated that, Last year we bought two cold vans...we are now tension free at the time of moving the product in long distance.'

\section{Research Implication}

This study establishes a model of supply chain risk management based on resource based view (RVB) and existing literatures (Figure 1). In this model, dairy supply chain risks are categorised from the sustainability perspective where they are linked with social, economic and environmental issues and are embedded in storage, processing and distribution level. In terms of theoretical implication, this study deals with a research framework in the light of contingency theory and sustainability theory by which different risk issues of dairy supply chain has 


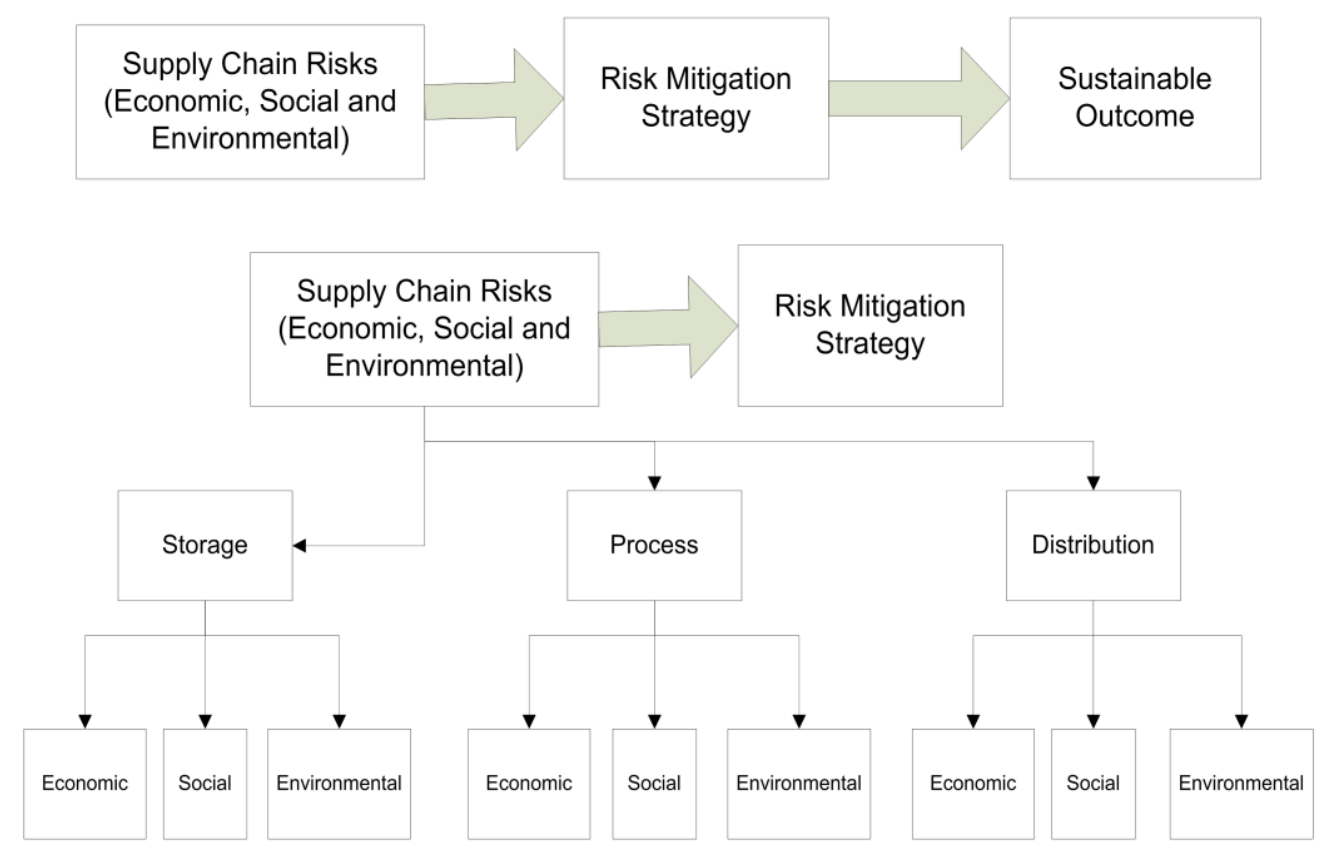

Figure 1. Dairy supply chain risk mitigation strategy model

been categorised. Effective and possible risk mitigation strategies have been revealed from the content analysis. Thus this research will produce additional knowledge and contribute significantly on the theoretical aspects of dairy supply chain risk management.

Adoption of sustainability in supply chain management is challenging because there are pressures from surrounded stakeholders to integrate sustainnable components in supply chain management. Dairy supply chain risks are more situational, contingent upon environmental uncertainty, technology and organisational size. Moreover, this industry directly or indirectly involves significant number of people for their livelihood. This research will thus improve the existing problems relating to achieving sustainability in the context of current Dairy supply chain risks. It is also expected that the practical application of the study will contribute significantly to the dairy sector of Bangladesh in terms of mitigating existing risks.

\section{Conclusion}

The main contribution of this paper is to present a comprehensive idea regarding the main factors and variables of different risk issues associated with the dairy sector in Bangladesh. A qualitative field study approach has been taken to do so. Ten interviews have been taken from two semi-structured and formal dairy farms. Both of the farms are rapidly growing and confronting different risks within their existing operations. Various common risk factors and variables have been identified from the interviews of the key persons of these two case industries that need to be mitigated. The researcher transcribed the interviews and analysed the contents thoroughly using a structured process. Possible appropriate risk mitigation strategies have been also identified from this study. The findings generally supported a contingency framework for identifying and categorising supply chain risk issues associated with the dairy sector of Bangladesh using the context of sustainability. Furthermore, it will explore the possible risk mitigation strategies which will improve facets of contingency theory in expounding supply chain risk management in dairy industry. This study does not include any outcome after risk mitigation. It will be interesting to explore the sustainable outcome after applying the proposed mitigation strategies. So future research could be done on sustainable outcomes and the researcher will also attempt to further examine the model by taking quantitative method through empirical surveys.

\section{References}

1. Thun, J.H., and Hoenig, D., An Empirical Analysis of Supply Chain Risk Management in the German Automotive Industry, International Journal of Production Economics, 131, 2011, pp. 242-249.

2. Giunipero, L.C, and Eltantawy, R.A., Securing the Upstream Supply Chain: A Risk Management Approach, International Journal of Physical Distribution \& Logistics Management, 34(9), 2004, pp. 698-713. 
3. Mishra, P.K., and Shekhar, B.R., Impact of Risks and Uncertainties on Supply Chain: A Dairy Industry Perspective, Journal of Management Research, 3(2:E11), 2011, pp. 1-18.

4. Curtis, M., Milking the Poor: How EU Subsidies Hurt Dairy Producers in Bangladesh, Dhaka, 2011. Available from http://www. Actionaid.org/ eu/publications/milking-the-poor.

5. FAOSTAT, Sharing Development Knowledge About Asia and The Pacific, ADB Institute 2005. Available from http://www.adbi.org/3rdparty cdrom/2005/06/01/1507.fao.agriculture.statistics/.

6. Shahnaz, P., Shimazaki, K., and Kato, I., Mil and Milk Prodicts in Bangladesh, Journal of Rakuno Gakuen University, 29(1), 2004, pp. 9-16.

7. Halder, S.R., and Barua, P., Dairy Production, Consumption and Marketing in Bangladesh, Dhaka: Research \& Evaluation Division BRAC, 2003.

8. DLS. Development and Activities of Livestock-An Overview, Dhaka: Department of Livestock Services, Bangladesh, 2005.

9. Bari, Md. E., Action Plan for Dairy Development in Bangladesh. In Overview of the Livestock in Bangladesh, Dhaka: Grameen Motsho O Pashusampad Foundation, Grameen Bank, 2008.

10. Haque, S A M Anwarul, Bangladesh: Social Gains from Dairy Development, Smallholder Dairy Development: Lessons Learned in Asia, 2009, pp. 8-21.

11. Karim, Z., Huque, K.S., Hussain, M.G., Ali, Z., and Hossain, M., Growth and Development Potential of Livestock and Fisheries in Bangladesh, In Bangladesh Food Security Investment Forum, Dhaka, 2010.

12. Ghosh, A.K., and Maharjan, K.L., Impacts of Dairy Cooperative on Rural Income Generation in Bangladesh, Journal of International Development and Cooperation, 8(1), 2001, pp. 67-90.

13. Shamsuddoha, A.K., and Edwards, G., Dairy Industry in Bangladesh: Problems and Prospects. In AARES 2000 Conference, School of Business, La Trobe University.

14. Aitken, J.M., Supply Chain Integration within the Context of a Supplier Association: Case Studies of Four Supplier Associations, Cranfield University, 1998.

15. Svensson, G., A Conceptual Framework for the Analysis of Vulnerability in Supply Chains, International Journal of Physical Distribution \& Logistics Management, 30(9/10), 2000, pp. 21-35.

16. Hendricks, K.B., and Singhal, V.R., The Effect of Supply Chain Glitches on Shareholder Value, Journal of Operations Management, 21(5), 2003, pp. 501-522.

17. Tang, Ou, Perspectives in Supply Chain Risk Management, International Journal of Production Economics, 103(2), 2006, pp. 451-488.
18. Jüttner, U., Peck, H. and Christopher, M., Supply Chain Risk Management: Outlining an Agenda for Future Research, International Journal of Logistics: Research \& Applications, 6(4), 2003, pp. 197-210.

19. Rao, S., and Goldsby, T.J., Supply Chain Risks: A Review and Typology, The International Journal of Logistics Management, 20(1), 2009, pp. 97-123.

20. Miller, K., A Framework for Integrated Risk Management in International Business, Journal of International Business Studies, 23(2), 1992, pp. 311-31.

21. Ghani, N., and Rahman, M.H., Sustainable Dairy-Sector Development for Poverty Reduction In APO Seminar on Sustainable Dairy-sector Development for Poverty Reduction, Pakistan, 2004.

22. Food, R.D., Rangpur Dairy. edited by Rangpur Dairy \& Food Products Limited. Dhaka, 2011.

23. Faye, B., and Loiseau, G., Sources of Contamination in Dairy Supply Chains and Approaches to Quality Control, Paper read at International Cooperation in International Research for Agricultural Development (CIRAD) -FAO, at Montpellier, France, 2002.

24. Choudhary, V., van Engelen, A., Sebadduka, S. and Valdivia, P., Uganda Dairy Supply Chain Risk Assessment, Switzerland World Bank Group, 2011.

25. Khanna, R.S., Sustainable Development of the Cottage Dairy Sector in Asia and the Pacific Challenges and Opportunities, In The Seminar on Sustainable Dairy-sector Development for Poverty Reduction, Faisalabad: Asian Productivity Organization (APO), Government of Pakis$\tan , 2004$.

26. Zikmund, W., Babin, B., Carr, J., and Griffin, M., Business Research Methods: Cengage Learning, 2012.

27. Eisenhardt, K.M., Building Theories from Case Study Research, Academy of Management Review, 14(4), 1989, pp. 532-550.

28. Whiteley, A., McCabe, M., Buoy, L., Howie, F., Klass, D., Latham, J., Bickley, M., and Luckeenarain, L., Planning the Qualitative Research Interview, Graduate School of Businees Working Paper Series 15, Curtin University of Technology, 1998.

29.Zikmund, W.G., Business Research Methods, Fort Worth, TX: Dryden Press, 2000.

30. Corbin, J., and Strauss, A., Basics of Qualitative Research, Thousand Oaks, CA: Sage, 2008.

31. Miles, M.B., and Huberman. A.M., An Expanded Source Book: Qualitative Data Analysis, Thousand Oaks, CA: Sage, 1994.

32. Quaddus, M., and Jun Xu, Adoption and Diffusion of Knowledge Management Systems: Field 
Studies of Factors and Variables. KnowledgeBased Systems,18(2), 2005, pp.107-115.

33. Berg, B.L., Qualitative Research Methods for the Social Sciences. 5, Pearson Boston, 2004.

34. Finch, P., Supply Chain Risk Management. Supply Chain Management: An International Journal, 9(2), 2004, pp. 183-196.

35. Akcaoz, H., Kizilay, H., and Ozcatalbas, O., Risk Management Strategies in Dairy Farming: A Case Study in Turkey, Journal of Animal and Veterinary Advances, 8(5), 2009, pp. 949-958.

36. Carter, C.R., and Rogers, D. S., A Framework of Sustainable Supply Chain Management: Moving toward New Theory, International Journal of Physical Distribution \& Logistics Management, 38(5), 2008, pp. 360-387.

37. Raha, S.K., and Talukder, R.K., Vertical Integration in the Dairy Sector in Bangladesh the Case of Bangladesh Milk Producers Co-operative Union Ltd. Bangladesh Journal of Political Economy, 20(1),2004.

38. Blos, M.F., Quaddus, M., Wee, H.M., and Watanabe, K., Supply Chain Risk Management (SCRM): A Case Study on the Automotive and Electronic Industries in Brazil, Supply Chain Management: An International Journal, 14(4), 2009, pp. 247-252.

39. Manuj, I., and Mentzer, J.T., Global Supply Chain Risk Management, Journal of Business Logistics, 29(1), 2008, pp.133-155.
40. Chowdhury, M.S., Overcoming Entrepreneurship Development Constraints: The Case of Bangladesh, Journal of Enterprising Communities: People and Places in the Global Economy, 1(3), 2007, pp. 240-251.

\section{Appendices}

Excerpts of interview questions (probed when required)

1. How does your organisation determine what supply chain risks exist?

2. What are the risks that your organisation is facing?

3. What risks do exist at storage level?

4. How often these risks may arise?

5. How these risks could be mitigated?

6. What will be the sustainable outcomes if these risks could be mitigated properly?

7. What risks do exist at processing level?

8. How often these risks may arise?

9. How these risks could be mitigated?

10. What will be the sustainable outcomes if these risks could be mitigated properly?

11. What risks do exist at distribution level?

12. How often these risks may arise?

13. How these risks could be mitigated?

14. What will be the sustainable outcomes if these risks could be mitigated properly? 